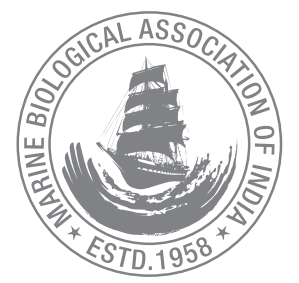

\title{
Plastic pollution in the islands of Laccadive Archipelago and its possible impact on the atoll ecosystem
}

\author{
P. Kaladharan ${ }^{1 *}$ and A. Anasukoya ${ }^{2}$ \\ ${ }^{\prime}$ ICAR-Central Marine Fisheries Research Institute, Cochin, Kerala- 682 018, India. \\ ${ }^{2}$ Research Centre of ICAR- Central Marine Fisheries Research Institute, Kozhikode, Kerala-673 005, India. \\ *Correspondence e-mail: kaladharanep@gmail.com
}

Received: 22 Feb 2020 Accepted: 28 July 2020 Published: 30 July 2020

\begin{abstract}
All the islands of Laccadive Archipelago including the inhabited ones are known comparatively less impacted from anthropogenic means as they are far and free from polluting industries. However, it is estimated that beach debris in ten of the inhabited islands show mean quantity of $10.567 \mathrm{~g} / \mathrm{m}^{2}$ which includes PET and glass bottles, plastic carry bags, HDPE and nylon ropes, cement bags, net pieces, footwear and insulators like PUF, styrofoam and thermocol pieces when observed quarterly for one year period during October 2013 to September 2014. Minicoy Island accounted for maximum quantity $\left(31.73 \mathrm{~g} / \mathrm{m}^{2}\right)$ and Kiltan Island accounted for minimum value $\left(4.53 \mathrm{~g} / \mathrm{m}^{2}\right)$ of beach debris. Plastic thin carry bags and containers of household products account for $40 \%$ among the beach litter which is much higher than the national average of $14 \%$ reported for the entire coastline. The quantity of beach debris in the islands was proportional to the number of island population, except for Kavarathi Island which registered the maximum per capita share of $17.5 \mathrm{~kg} / \mathrm{head}$ and the lowest $(2.19 \mathrm{~kg} / \mathrm{head})$ by Kiltan Island. Thin carry bags and sheets smother over seagrass and seaweed beds and choke the macrophytes while damage the biota beneath. Upon photolysis over a period of time, these plastic bags can be fragmented and become microplastics. These tiny particles of plastics can enter into the food chain of fragile atoll ecosystem as well as can settle on the coral polyps which may lead to their mortality. The Island Administration can enforce strict legislation to discard plastics
\end{abstract}

after use in designated places only and to encourage reuse, reduce and recycle the plastic materials.

Keywords: Beach debris, microplastics, atoll ecosystem, plastic pollution, percapita share

\section{Introduction}

Beach debris including the non-biodegradable waste materials find their way to sea either through river runoff, or directly through anthropogenic interventions in different proportions. Plastic materials also end up in the marine environment when accidentally lost, carelessly handled (Wilber, 1987) or left behind by beachgoers (Pruter, 1987). The threat of plastics to the marine environment has been ignored for a long time, and its seriousness has been only recently recognised (Stefatos et al., 1999). Around the globe nearly 300 million tonnes of plastic are produced annually; of which 8 million tonnes enter the oceans each year. $80 \%$ of marine plastics originate from land sources - impacting on all habitats and threatening wildlife, food safety, human health and contributing to climate change (Law, 2017). The United Nations Environmental Programme (UNEP) considers 
plastic marine debris and its ability to transport harmful substances as one of the main emerging issues affecting the coastal environment.

Quantity and composition of beach debris from India are available from various parts such as Nicobar Islands (Dharani et al., 2003; Sahu and Balakrishnan, 2019), Karnataka coast (Sridhar et al., 2009), northern Gulf of Mannar (Ganesapandian et al., 2011), select beaches of Kerala, Karnataka and Tamil Nadu (Kaladharan et al., 2012), some urban beaches in Mumbai (Jayasiri et al., 2013), Mangalore coast (Bindu et al., 2014) and a comprehensive account from the entire peninsular and archipelagic coasts of India (Kaladharan et al., 2017). All the islands of Laccadive Archipelago including the inhabited ones are known comparatively less impacted from anthropogenic means as they are free from polluting industries. However, intertidal areas of majority of lagoons of Lakshadweep Islands are contaminated with beach debris abandoned by the Island population and the tourists. Hence an attempt is made to quantify and categorize the beach debris from the beaches of 10 inhabited Islands.

\section{Material and methods}

The survey for beach debris was conducted in 10 inhabited

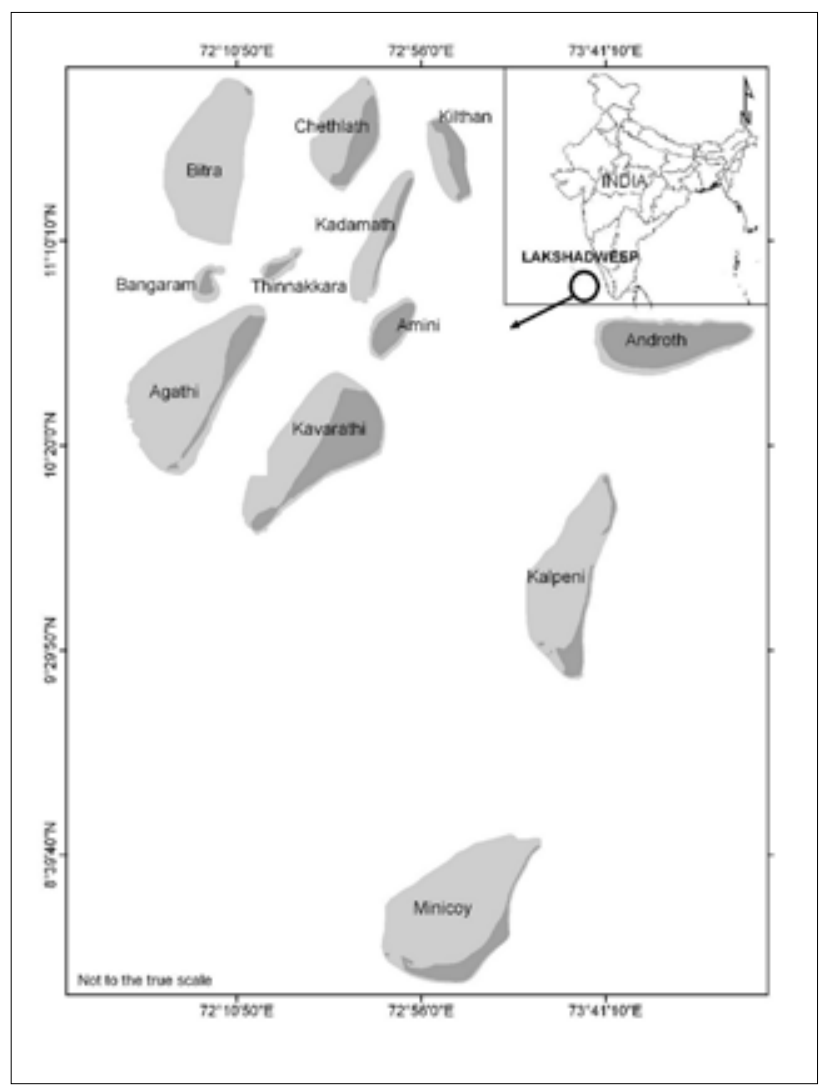

Fig. 1. Map of Lakshadweep Islands showing the 10 inhabited Islands
Atolls (Fig.1) whose details such as name, area, geographic locations etc. are given in Table 1.

From the 10 inhabited Atolls, sampling sites along the intertidal zone were selected systematically at every one $\mathrm{km}$ intervals on a line transect around the island using a rope quadrat of $10 \times 10 \mathrm{~m}$. All debris larger than $2.5 \mathrm{~cm}$ in diameter/ length that occurred within the quadrats laid between the low tide mark and the highest tide mark on the shore around the island were collected, cleaned of adhering sand and moisture and classified into six categories (Kaladharan et al., 2017) as shown below within one year period from October 2013 to September 2014.

Debris thus segregated were counted and weighed by group (drained weight) using a portable balance in the survey sites itself. Debris counted and weighed on the beach were removed after the survey every time. The mean values $\left(\mathrm{g} / \mathrm{m}^{2}\right)$ of beach debris for each Atoll were calculated using Excel software. From the mean values of each Atoll total quantity of beach litter $(\mathrm{kg})$ was calculated by multiplying the mean value with the total land area of respective Atolls (ICMAM, 2010). Similarly per capita share of beach debris was also calculated by dividing the total quantity for the Atoll with the respective population (Marine Census, 2010) without taking into account the number of tourists and visitors to the Atolls.

Table 1. The names and details of the Atolls in the UT of Lakshadweep where beach debris study carried out.

\begin{tabular}{|c|c|c|c|c|}
\hline SI.No & Name of Atoll & Geographic Location & $\begin{array}{l}\text { Land area } \\
(\mathrm{sq} . \mathrm{Km})\end{array}$ & $\begin{array}{l}\text { Lagoon } \\
\text { area (sq } \\
\mathrm{Km})\end{array}$ \\
\hline \multirow{2}{*}{1} & \multirow{2}{*}{ Agathi } & Lat.10 $52^{\prime} \mathrm{N}$ & \multirow{2}{*}{2.71} & \multirow{2}{*}{8.8} \\
\hline & & Long.72¹1' E & & \\
\hline \multirow{2}{*}{2} & \multirow{2}{*}{ Amini } & Lat. $11^{\circ} 07^{\prime} \mathrm{N}$ & \multirow{2}{*}{2.59} & \multirow{2}{*}{3.6} \\
\hline & & Long. $72^{\circ} 44^{\prime} \mathrm{E}$ & & \\
\hline \multirow{2}{*}{3} & \multirow{2}{*}{ Androth } & Lat. $10^{\circ} 49^{\prime} \mathrm{N}$ & \multirow{2}{*}{4.8} & \multirow{2}{*}{-} \\
\hline & & Long. $73^{\circ} 4^{\prime} \mathrm{E}$ & & \\
\hline \multirow{2}{*}{4} & \multirow{2}{*}{ Bitra } & Lat.11 ${ }^{\circ} 36^{\prime} \mathrm{N}$ & \multirow{2}{*}{0.1} & \multirow{2}{*}{2.29} \\
\hline & & Long.72¹0' E & & \\
\hline \multirow{2}{*}{5} & \multirow{2}{*}{ Chetlat } & Lat. $11^{\circ} 42^{\prime} \mathrm{N}$ & \multirow{2}{*}{1.04} & \multirow{2}{*}{1.4} \\
\hline & & Long. $72^{\circ} 43^{\prime} \mathrm{E}$ & & \\
\hline \multirow{2}{*}{6} & \multirow{2}{*}{ Kadmat } & 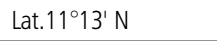 & \multirow{2}{*}{3.13} & \multirow{2}{*}{13.3} \\
\hline & & Long. $73^{\circ} 39^{\prime} \mathrm{E}$ & & \\
\hline \multirow{2}{*}{7} & \multirow{2}{*}{ Kalpeni } & Lat. $10^{\circ} 05^{\prime} \mathrm{N}$ & \multirow{2}{*}{2.28} & \multirow{2}{*}{5.2} \\
\hline & & Long.72¹1' E & & \\
\hline \multirow{2}{*}{8} & \multirow{2}{*}{ Kavarathi } & Lat. $10^{\circ} 33^{\prime} \mathrm{N}$ & \multirow{2}{*}{3.63} & \multirow{2}{*}{6.75} \\
\hline & & Long. $72^{\circ} 38^{\prime} \mathrm{E}$ & & \\
\hline \multirow{2}{*}{9} & \multirow{2}{*}{ Kiltan } & Lat. $11^{\circ} 29^{\prime} \mathrm{N}$ & \multirow{2}{*}{1.63} & \multirow{2}{*}{2.02} \\
\hline & & Long. $73^{\circ} 01^{\prime} \mathrm{E}$ & & \\
\hline 10 & Mini & Lat. $8^{\circ} 17^{\prime} \mathrm{N}$ & & 21 \\
\hline 10 & IVIIIICoy & Long. $73^{\circ} 04^{\prime} \mathrm{E}$ & 4.31 & 21.8 \\
\hline
\end{tabular}




\section{Results and discussion}

The Laccadives or the Lakshadweep Islands are the northernmost of the Lakshadweep-Maldives-Chagos group of islands, which are on the top of a vast undersea mountain range, the ChagosLaccadive Ridge (Ashalatha et al., 1991) as an archipelago is formed of 36 islands comprising 12 atolls, 3 reefs, 5 submerged banks and 10 inhabited islands with an area of $32 \mathrm{sq} \mathrm{km}$. It is estimated that beach debris in the ten inhabited islands studied show mean value of $10.567 \mathrm{~g} / \mathrm{m}^{2}$ which includes PET (polyethylene terephthalate) and glass bottles, plastic carry bags, HDPE (high density polyethylene) and nylon ropes, net pieces, long lines, cigarette lighters, footwear and insulators like PUF (polyurethane foam), styrofoam and thermocol pieces. Distribution of beach litter recorded maximum in Minicoy Island and minimum in Kiltan Island (Fig 2). In both these islands the fishing related litter (A-group) were negligible or nil (Table 2). Plastic thin carry bags and wrappers of household products (B-group) formed the major composition in all the Islands and registered maximum per unit area in Minicoy Island which accounted for $50 \%$ among the beach debris, while the Androth Island that generated lower quantity of beach litter registered $89 \%$ of house hold plastic items (Table 2). Lakshadweep Islands, the smallest Union Territory of India registered $40 \%$ of house hold plastics over the total debris which is much higher than

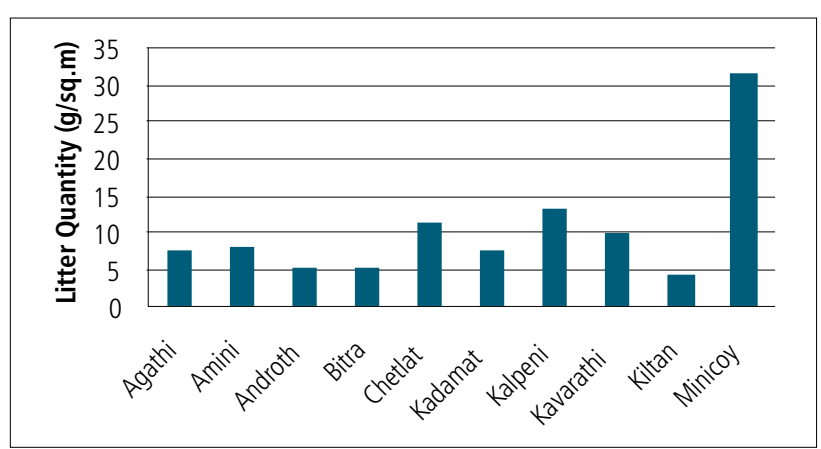

Fig. 2. Quantity of litter $(\mathrm{g} / \mathrm{m} 2)$ in the beaches of ten inhabited Lakshadweep Islands the national average of $14 \%$ of beach litter reported for the entire coastline by Kaladharan et al. (2017).

Plastic litter comprising mostly beverage and cosmetic bottles from South-east Asian countries has been reported accumulating along the shores of Great Nicobar by currents via the Malacca Strait, posing a threat to its rich and unique ecosystem (Darani et al., 2003; Sahu and Balakrishnan, 2019). Darani et al. (2003) had already quantified the share of plastic litter being swept in to the shores of Great Nicobar Island from Malaysia (40.5\%), Indonesia (23.9\%), Thailand (16.3\%) and Singapore (7.4\%). Similar to the Great Nicobar Island in the Andaman Nicobar archipelago, Minicoy Island, which is the southern most island and so proximate to Maldives Ridge has the highest deposition

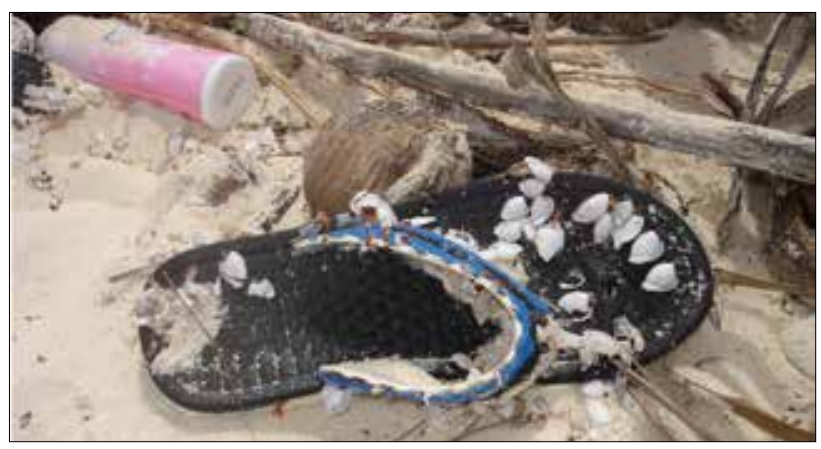

Fig. 3. View of barnacles settled on a beach litter

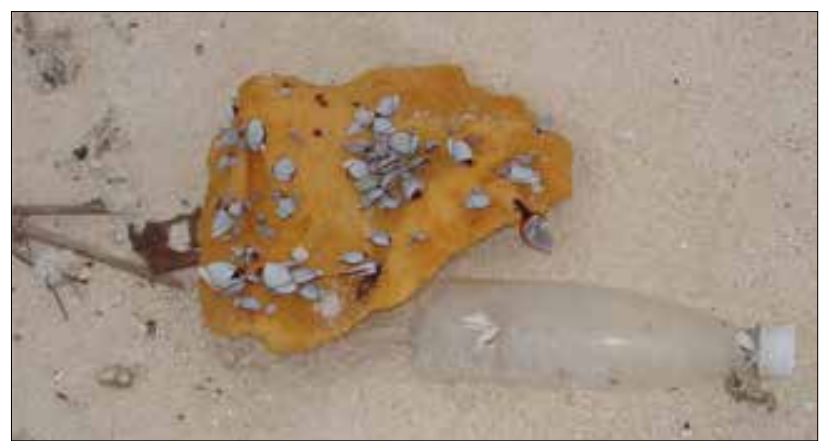

Fig. 4. View of drifted piece of litter found in the shores of Minicoy Island

Table 2. Composition of beach litter $\left(A-F ~ g / \mathrm{m}^{2}\right)$ and the relative percentage of house hold plastics (B) over the total quantity of litter

\begin{tabular}{llllllll}
\hline Name of Islands & A & B & C & D & E & F & \% of B over total \\
\hline Agathi & 0.45 & 2.85 & 2.15 & 0.60 & 0.00 & 1.59 & 38.8 \\
\hline Amini & 0.05 & 2.67 & 2.48 & 1.35 & 1.09 & 0.57 & 24.9 \\
\hline Androth & 0.00 & 4.03 & 0.23 & 0.50 & 0.08 & 0.67 & 89.0 \\
\hline Bitra & 0.54 & 2.09 & 1.47 & 1.06 & 0.00 & 0.13 & 39.5 \\
\hline Chetlat & 1.78 & 4.35 & 3.75 & 0.84 & 0.06 & 0.54 & 37.7 \\
\hline Kadamat & 2.48 & 2.08 & 1.05 & 0.49 & 0.00 & 1.84 & 21.0 \\
\hline Kalpeni & 7.69 & 3.49 & 1.80 & 0.00 & 0.00 & 0.37 & 26.0 \\
\hline Kavarathi & 0.51 & 5.28 & 3.02 & 0.14 & 0.15 & 1.01 & 48.6 \\
\hline Kiltan & 1.59 & 1.01 & 1.61 & 0.23 & 0.00 & 0.09 & 22.0 \\
\hline Minicoy & 0.00 & 15.85 & 10.84 & 0.00 & 0.00 & 5.04 & 50.0 \\
\hline Mean & $1.51 \pm 2.2$ & $4.37 \pm 4$ & $2.84 \pm 2.8$ & $0.52 \pm .4$ & $0.14 \pm 0.3$ & $1.19 \pm 1.4$ & $39.75 \pm 19.2$ \\
\hline
\end{tabular}


of beach litter (Fig. 2) Many floating debris collected from Minicoy and Kiltan Islands have deposition of barnacles and other oceanic foulants (Figs. 3 and 4) indicating that these debris particles have drifted a long distances floating before settling to the shore. Barnacles such as Lepas spp. are considered as foundation species on plastic debris (Gil and Pfaller, 2016).

The quantity of beach debris in the islands was directly proportional to the number of island population, except for Kavarathi Island (Table 3) which might be due to the higher number of non-resident population including the Government employees and hence the highest per capita share of $17.53 \mathrm{~kg} / \mathrm{head}$. Visitors and tourists do play major role in littering the beaches as evident from the per capita share of litter from the Islands of socio- cultural and tourism importance (Table 3).

Marine debris scattered on beaches can impair the aesthetic value of beaches and can create an eyesore for tourists and beachgoers. Marine debris is a source of serious damage to

Table 3. Per capita share of beach litter in the inhabited Islands

\begin{tabular}{llllll}
\hline $\begin{array}{l}\text { Name of } \\
\text { Islands }\end{array}$ & $\begin{array}{l}\text { Fisher } \\
\text { population }\end{array}$ & Qty $\left(\mathrm{g} / \mathrm{m}^{2}\right)$ & $\begin{array}{l}\text { Land area } \\
(\mathrm{sq} . \mathrm{km})\end{array}$ & $\begin{array}{l}\text { Total } \\
\text { debris }(\mathrm{kg})\end{array}$ & $\begin{array}{l}\text { Per capita } \\
(\mathrm{kg} / \mathrm{head})\end{array}$ \\
\hline Agathi & 3284 & 7.674 & 2.71 & 20796.54 & 6.33 \\
\hline Amini & 3628 & 8.213 & 2.59 & 21271.67 & 5.86 \\
\hline Androth & 4637 & 5.51 & 4.8 & 26448.00 & 5.70 \\
\hline Bitra & 154 & 5.29 & 0.1 & 529.00 & 3.44 \\
\hline Chetlat & 1287 & 11.32 & 1.04 & 11772.80 & 9.15 \\
\hline Kadamat & 2949 & 7.94 & 3.13 & 24852.20 & 8.43 \\
\hline Kalpeni & 4982 & 13.35 & 2.28 & 30438.00 & 6.11 \\
\hline Kavarathi & 2093 & 10.11 & 3.63 & 36699.30 & 17.53 \\
\hline Kiltan & 3371 & 4.533 & 1.63 & 7388.79 & 2.19 \\
\hline Minicoy & 8426 & 31.73 & 4.37 & 138660.10 & 16.46 \\
\hline Total & 34811 & - & 26.29 & 277700.80 & - \\
\hline Mean & - & $10.56 \pm 7.53-$ & - & $8.12 \pm 4.84$ \\
\hline
\end{tabular}

marine lives, ecosystems, fisheries, and navigational safety. Upon photolysis over a period of time, plastic bags and carry bags can be fragmented and become microplastics. These tiny particles of plastics can enter into the food chain of fragile atoll ecosystem as well as can settle on the coral polyps resulting in their mortality. Marine turtles use a variety of habitats including seagrass meadows, their migratory behaviour and complex life histories expose them to a wide range of anthropogenic stressors, including marine plastic pollution. Beach litter may also entangle nesting females or emerging hatchlings of turtles. Transfer of chemicals to marine biota through the marine debris especially plastics has also been recorded recently (Derraik, 2002; Hong et al., 2013; Rochman et al., 2013) which might cause deleterious effects on the sensitive and fragile ecosystem.

Although plastic is omnipresent and widespread pollutant, it is an important and inevitable item for the inhabitants of Lakshadweep Islands to protect their belongings, valuables and food materials from the vagaries of sea and rain water. So a total ban for plastics may not be feasible in the Lakshadweep. However, the Island Administration can enforce strict legislation to discard plastics after use in designated places only and to encourage reuse, reduce and recycle the plastic materials.

\section{References}

Ashalatha, B., C. Subrahmanyam and R. N. Singh. 1991. Origin and compensation of Chagos-Laccadive ridge, Indian Ocean, from admittance analysis of gravity and bathymetry data. Earth and Planetary Science Letters. 105 (1-3): 47-54.

Bindu Sulochanan, G. S. Bhat, S. Lavanya, A. P. Dineshbabu and P. Kaladharan. 2014. Preliminary assessment of ecosystem process and marine litter in the beaches of Mangalore. Indian J. Geo-Mar. Sci., 43(9): 1-6.

Derraik, J. G. B. 2002. The pollution of the marine environment by plastic debris: a review. Mar. Pollut. Bull., 44: 842-852.

Dharani, G., A. K.Abdul Nazar, R. Venkatesan and M. Ravindran. 2003. Marine debris in Great Nicobar. Curr. Sci., 85(5): 574-575.

Ganesapandian, S., S. Manikandan and A. K. Kumaraguru. 2011. Marine litter in the northernpart of Gulf of Mannar, southeast coast of India. Res. J. Environ. Sci., 5: 471-478.

Gil, M. A. and J. B. Pfaller. 2016. Oceanic barnacles act as foundation species on plastic debris: implications for marine dispersal. Sci. Rep., 6: 19987.

Hong, S., J. Lee, Y. C. Jang, Y. J. Kim, H. J. Kim, D. Han, S. H. Hong, D. Kang and W. J. Shim. 2013. Impacts of marine debris on wild animals in the coastal area of Korea. Mar. Pollut. Bull., 66:117-124.

ICMAM. 2010. Report-Integrated Coastal and Marine Area Management Project, Ministry of Earth Sciences, Government of India.

Jayasiri, H.B., C.S. Purushothaman and A. Vennila. 2013. Plastic litter accumulation on high- water strandline of urban beaches in Mumbai, India. Environ. Monit. Assess., 185: 7709-7719.

Kaladharan, P., K. Vijayakumaran, V. V. Singh, P. S. Asha, Bindu Sulochanan, P. K. Asokan, K. K. Valsala, S. Veena, L. Jayasankaran and H.M. Bhint, 2012. Assessment of certain Anthropogenic Interventions and their Impacts along the Indian Coastline. Fish. Technol., 49: 32-37.

Kaladharan, P., K. Vijayakumaran, V. V. Singh, D. Prema, P. S. Asha, Bindu Sulochanan, P. Hemasankari, L. Loveson Edward, Shelton Padua, S. Veena, A. Anasukoya and H. M. Bhint. 2017. Prevalence of marine litter along the Indian beaches: A Preliminary account on its status and composition. J. Mar. Biol. Assn. India, 59 (1): 19-24.

Law, K. L. 2017. Plastics in the marine environment. Annu. Rev. Mar. Sci., 9: 205-229.

Marine Census, 2010, Marine Fisheries Census, Part 1, Government of India, Ministry of Agriculture, DAHDF and ICAR- CMFRI Kochi, 98 p.

Pruter, A. T. 1987. Sources, quantities and distribution of persistent plastics in the marine environment. Mar. Pollut. Bull., 18: 305-310.

Rochman, C. M., E. Hoh, T. Kurobe and S. J. Teh. 2013. Ingested plastic transfers hazardous chemicals to fish and induces hepatic stress. Scientific Reports 3. Article number: 3263

Sahu, B. and B. Balakrishnan. 2019. Foreign origin plastic litter predominate in Great Nicobar Island, a biosphere reserve. Curr. Sci., 117(7): 1125-1128.

Sridhar, K. R., B. Deviprasad, K. S. Karamchand and R. Bhat, 2009. Plastic litter along the beaches of Karnataka, southwest coast of India. Asian J. Water Environ. Pollut., 6: 87-93.

Stefatos, A., M. Charalampakis, G. Papatheodorou and G. Ferentinos. 1999. Marine debris On the seafloor of the Mediterranean Sea: examples from two enclosed gulfs in Western Greece. Mar. Pollut. Bull., 36: 389-393.

Wilber, R. J. 1987. Plastic in the North Atlantic. Oceanus, 30: 61-68 